This item was submitted to Loughborough's Research Repository by the author.

Items in Figshare are protected by copyright, with all rights reserved, unless otherwise indicated.

\title{
Fiscal consolidation and financial reforms
}

PLEASE CITE THE PUBLISHED VERSION

http://dx.doi.org/10.1080/00036846.2015.1021457

\section{PUBLISHER}

(C) Taylor \& Francis

\section{VERSION}

AM (Accepted Manuscript)

\section{PUBLISHER STATEMENT}

This work is made available according to the conditions of the Creative Commons Attribution-NonCommercialNoDerivatives 4.0 International (CC BY-NC-ND 4.0) licence. Full details of this licence are available at: https://creativecommons.org/licenses/by-nc-nd/4.0/

\section{LICENCE}

CC BY-NC-ND 4.0

\section{REPOSITORY RECORD}

Agnello, Luca, Vitor Castro, Joao Tovar Jalles, and Ricardo M. Sousa. 2019. "Fiscal Consolidation and Financial Reforms". figshare. https://hdl.handle.net/2134/25016. 


\title{
Fiscal Consolidation and Financial Reforms*
}

\author{
Luca Agnello $^{\#}$ Vitor Castro ${ }^{ \pm}$João Tovar Jalles ${ }^{+}$Ricardo M. Sousa ${ }^{\$}$
}

\begin{abstract}
We use a rare events logistic regression model as well as traditional probit and logit models to investigate the impact of fiscal consolidation on the likelihood of financial reforms for a panel of 17 countries over the period 1980-2005. We show that large austerity plans, mainly implemented through spending-cuts rather than tax hikes, promote financial reforms. By considering reforms affecting specific areas of the financial sector, we find that the banking sector reforms and domestic finance reforms are more likely to occur when fiscal adjustments are put in place. Interestingly, while banking sector reforms are mainly prompted during periods of tax-driven consolidations, spending-cuts driven consolidation packages seem to propel the implementation of domestic finance reforms. Finally, we show that higher inflation, lower degree of trade openness, a deterioration of financial conditions and, to some extent, a fall in the degree of competitiveness enhance the probability of financial reforms.
\end{abstract}

JEL: Fiscal consolidation, financial reforms, macroeconomic determinants, rare events logit model.

Keywords: P11, P16, P34, N20, G28.

\footnotetext{
${ }^{*}$ The authors gratefully acknowledge the constructive comments made by participants to the Third International Symposium in Computational Economics and Finance (ISCEF2014: www.iscef.com), April 10-12, 2014, Paris, France. The opinions expressed herein are those of the authors and do not necessarily reflect those of the OECD or its member countries. The usual disclaimer applies.

\# University of Palermo, Department of Economics, Business and Statistics (DEAS), Viale delle Scienze, 90128 Palermo, Italy. Email: luca.agnello01@unipa.it.

${ }^{ \pm}$University of Coimbra, Faculty of Economics, Av. Dias da Silva, 165, 3004-512 - Coimbra, Portugal; University of Minho, Economic Policies Research Unit (NIPE), Campus of Gualtar, 4710-057 - Braga, Portugal. Email: vcastro@fe.uc.pt.

+ OECD, Economics Department, 2 rue Andre Pascal, 75775 CEDEX 16, Paris, France. Email: joao.jalles@oecd.org.

\$ University of Minho, Department of Economics and Economic Policies Research Unit (NIPE), Campus of Gualtar, 4710-057 - Braga, Portugal; London School of Economics and Political Science, LSE Alumni Association, Houghton Street, London WC2A 2AE, United Kingdom. E-mails: rjsousa@eeg.uminho.pt, rjsousa@alumni.lse.ac.uk.
} 


\section{Introduction}

The global financial crisis of 2008-2009 demanded quick responses from central banks and governments all over the world. These were typically designed with the goal of restoring economic growth in the short-term, but have also led to large fiscal deficits which culminated in the sovereign debt crisis.

When fiscal consolidation efforts started to be implemented in many OECD countries, the debate shifted towards questioning whether such adjustments could also be seen as catalysts for structural reforms in order to create the necessary conditions to a sustainable growth path.

Despite this, the impact of fiscal consolidation on structural reforms (in particular, financial reforms) has not been properly explored yet, with the evidence being rather limited to a few works evaluating the likelihood of structural reforms during periods of financial austerity (von Hagen et al., 2002; IMF, 2004; Duval and Elmeskov, 2005).

Theoretically, some authors view austerity times as narrowing the budgetary room of manoeuvre and, thus, as reducing the scope for reforms (European Commission, 2005; Deroose and Turrini, 2005; Buti, 2006) or even see fiscal consolidation and reforms as substitutes (Teulings, 2012). By contrast, others sustain that the beneficial effects derived from the improved public finance sustainability allow fiscal consolidation and structural reforms to go hand in hand (Rodrik, 1996; Bean, 1998; Calmfors, 2001).

Empirically, the scant evidence is also somewhat contradicting in that some authors suggest that fiscal adjustments can delay the implementation of some structural reforms (Annett and Debrun, 2004; Duval and Elmeskov, 2005), while other pieces of research uncover an important degree of complementarity between the two variables (Buti et al., 2007; Anderson et al., 2013).

In this paper, we use a rare events logit model and annual data for 17 countries over the period 1980-2005, and show that the size of fiscal consolidation programs (as measured in percentage of GDP) and, in particular, the size of spending-driven consolidations has a positive and significant impact in the likelihood of financial reforms: large fiscal adjustments driven by cuts in government spending raise the probability of the implementation of financial reforms.

While these results are broadly similar across the different dimensions of financial reforms (i.e. banking sector reforms, domestic finance reforms and capital account reforms), they point to three main differences. First, the likelihood of a financial reform increases during periods of fiscal consolidation, but only in the case of banking sector reforms and 
domestic finance reforms. Second, banking sector reforms are more likely to occur when taxdriven consolidations are put in place, but the same does not hold for the other categories of financial reforms. Third, in the case of capital account reforms, fiscal adjustments do not seem to matter, as this type of structural reform appears to depend more on economic conditions.

When we focus on the role played by a set of macroeconomic determinants, our empirical evidence shows that: (i) an increase in the inflation rate increases the probability of financial reforms, while a rise in the degree of openness reduces it; and (ii) a deterioration of financial conditions - as measured by an increase in the interest rate spread -, accelerates the path of banking sector reforms and domestic finance reforms, but changes in the real effective exchange rate only seem to contribute for the implementation of capital account reforms.

The empirical findings described above are robust across different econometric methodologies. In particular, they remain largely unchanged when we consider: 1) a probit model; and (2) a logit model.

We improve the existing literature along different ways. First, we are indebted to the work of Abiad and Mody (2005) who investigate the determinants of (large) financial reforms and (large) financial reversals. Our paper is also related with the research by Agnello et al. (2014b) who focus on the importance of the external aid provided by IMF adjustment programs, the Paris Club sovereign debt restructurings and the crisis episodes as drivers of financial reforms. It is also close in spirit with the work of Agnello et al. (2014a) who cover a broader set of structural reforms (including, in addition to financial reforms, trade reforms, capital account restrictions, labour market regulations and product market reforms) and emphasize the role played by globalization and the intensity of distributional conflict. In the current work, we assess the direct effect of fiscal consolidation programs on the probability of the implementation of financial reforms.

Second, we consider different typologies of fiscal consolidation programs (namely, by distinguishing between spending-driven and tax-driven episodes), and also control for their size effects (in percentage of GDP). These programs are identified using a narrative approach (Devries et al., 2011), which eliminates the endogenous dimension of the reaction of fiscal policy to the economic dynamics.

Third, we rely on a rare events logit model and, thus, correct for the small sample and rare events bias (King and Zeng, 1999a, 1999b, 2001).

Fourth, we highlight the relevance of the macroeconomic environment for the likelihood of financial reforms. More specifically, we take into account the impact of the 
contractionary periods, the inflation rate, the financial conditions (as proxied by the interest rate spread), the degree of trade openness and the real effective exchange rate on the probability of financial reforms.

The rest of the paper is organized as follows. Section 2 presents the literature on structural reforms. Section 3 describes the econometric framework. Section 4 discusses the data used in the study. Section 5 reports the empirical results, while Section 6 provides the sensitivity analysis. Finally, Section 6 concludes.

\section{Literature Review}

Weak economic conditions are typically seen as paving the way for structural reforms (Drazen and Grilli, 1993). Sharp output falls, increasing interest rate spreads and worsening current account conditions are among the most important contributors to the removal of obstacles to the implementation of reforms (Nelson, 1990; Haggard and Kaufman, 1992; Bates and Krueger, 1993).

In this context, von Hagen et al. (2002) find that the quality of fiscal adjustments, the "consolidation fatigue" and the macroeconomic conditions are determinants of longevity of budgetary consolidations, a result that is corroborated by Agnello et al. (2013a, 2013b). von Hagen and Strauch (2001) also highlight that although the initial debt level and the stance of the fiscal policy drive the choice of the consolidation strategy by the government, the monetary policy stance does not seem to be relevant in this matter. ${ }^{1}$ Adam et al. (2003) and Gupta et al. (2005) show that the composition of government spending, the occurrence of previous fiscal disruptions and the size of the gap in public finances help explaining the duration of fiscal consolidation programs in emerging countries. Additionally, Baldacci et al. (2004) find empirical evidence corroborating the idea that in order to achieve fiscal sustainability, spending-driven fiscal consolidations are needed in conjunction with reforms on the revenue side of the fiscal stance. The success of such fiscal adjustments also depends on the existence of political stability (for instance, in the form of parliamentary majorities) and on whether they are undertaken under IMF-supported programs.

\footnotetext{
1 Johannesson Lindén and Gayer (2012) also highlight the importance of real estate taxation for the purpose of contributing to fiscal consolidation. The authors emphasize its impact on macroeconomic stability and the fact that it impinges less strongly on growth than other sources of taxation, despite its unpopular nature. Jensen and Wöhlbier (2012) recall that the efforts to narrow the tax compliance gap and to improve the efficiency and the effectiveness of tax collection are especially relevant when countries face the need to implement fiscal consolidation measures.
} 
Recent work in the field of reforms also gives support to the "crisis induces-reform hypothesis" and suggests that a deterioration of the quality of institutions, a widening of the gap in the income distribution and an increase in political fragmentation deter the course of reforms (Agnello et al., 2014a). ${ }^{2}$ Moreover, debt crisis episodes, IMF-stabilization programmes and sovereign debt restructurings create favourable conditions for the implementation of financial reforms (Agnello et al., 2014b). ${ }^{3}$

The sovereign debt crisis experienced by many OECD countries (notably, EMU economies) has revived the debate among economists and policymakers on how a combination of fiscal consolidation and structural reforms can help countries to escape from the public debt trap and put the economy on the track of recovery (Padoan et al., 2013), while financial backstops allow countries to "buy time" (Padoan et al., 2012). In particular, it highlighted the need of assessing whether fiscal consolidation programs boost the likelihood of structural reforms or whether there is a trade-off between the two.

From a theoretical point of view, two main opposite views seem to prevail. The first one supports the idea that fiscal consolidation is hardly compatible with structural reforms. According to this view, the reduction of the budgetary room of manoeuvre following the adoption of a fiscal package may deter reforms. Put it differently, the budgetary costs related to the implementation of new reforms would require further fiscal adjustments in the shortrun. Thus, in austerity times, excessive tight constraints to fiscal policy would make the scope for reforms smaller (European Commission, 2005; Deroose and Turrini, 2005; Buti, 2006).

A second theoretical view provides arguments supporting the idea that both fiscal consolidations and structural reforms are not incompatible. Thus, credible fiscal consolidation plans could favour structural reforms because of the need to boost growth. By rising potential output, structural reforms contribute to an increase of the future tax base and, therefore, improve the long-run public finance sustainability (Rodrik, 1996; Bean, 1998; Calmfors, 2001).

From an empirical perspective, the link between fiscal consolidation and structural reforms has not been properly explored yet. In fact, only a few works have assessed whether structural reforms are favoured in times of austerity and, in most of the cases, the evidence is mixed. For instance, some authors find that fiscal consolidations may reduce the incentives for the implementation of labour market reforms, but do not seem to have a significant impact

\footnotetext{
${ }_{2}^{2}$ Agnello et al. (2012) find a negative relationship between financial reforms and the income gap.

${ }^{3}$ Bouthevillain and Dufrénot (2011) show that the nature of the fiscal adjustments also depends on features, such as the occasional and sudden occurrence of financial crises, thereby, making it difficult for governments to implement fixed-regime rules (Bouthevillain and Dufrénot, 2011).
} 
on product market or financial market reforms (Annett and Debrun, 2004; Duval and Elmeskov, 2005). Agnello et al. (2014c) investigate the effects of fiscal adjustments and labour market flexibility on unemployment. They show that tax-driven consolidations are particularly detrimental for unemployment, but labour market flexibility can help to dampen such effect. Anderson et al. (2013) use the IMF's Global Integrated Monetary and Fiscal model (GIMF) to explore the complementarities of structural reforms and fiscal consolidations in the euro area. Their results show that structural reforms in the core countries (i.e., those experiencing less acute sustainability issues) could offset the near-term negative impact on activity arising from fiscal consolidation.

This corroborates the theoretical assumption that a well-conceived consolidation plan should be associated to structural reform programmes, with the benefits of the latter compensating the costs of the former. Interestingly, this has been proven particularly true when governments are short-sighted. In this respect, Buti et al. (2007) finds that, by reducing the scope for expansionary policies, fiscal adjustments can act as catalysts for structural reform and, thus, as short-to-medium term growth engines. By contrast, if governments are forward-looking, it is more likely that structural reforms are disconnected from the consolidation programs, the reason being that both fiscal retrenchment and structural reforms improve potential output in the medium-to-long run.

\section{Econometric Methodology}

We employ a rare events logistic regression for dichotomous dependent variables to analyse the role played by fiscal consolidation (Consol), together with a set of macroeconomic variables $(\boldsymbol{X})$, in explaining the likelihood of financial reforms (FinRef). More specifically, we consider the following logistic model

$$
\begin{aligned}
& \operatorname{Prob}\left(\text { FinRef }_{i t}=1 \mid \mathbf{Z}_{\mathbf{i t}}\right)=\Phi\left(\mathbf{Z}_{\mathbf{i t}}^{\prime} \vartheta\right) \\
& \Leftrightarrow \operatorname{Prob}\left(\text { FinRef }_{i t}=1 \mid \mathbf{X}_{\mathbf{i t}}, \text { Consol }_{i t}\right)=\Phi\left(\alpha_{\mathbf{i}}+\mathbf{X}_{\mathbf{i t}}{ }^{\prime} \boldsymbol{\beta}+\text { Consol }_{\mathbf{i t}} \gamma\right),
\end{aligned}
$$

with $i=1, \ldots, 17, t=1980, \ldots, 2005$, and where $\Phi(\cdot)=\frac{1}{1+\mathbf{e}^{-\left(\mathbf{Z}_{\mathbf{i t}} \vartheta\right)}}=\frac{1}{1+\mathbf{e}^{-\left(\alpha_{\mathbf{i}}+\mathbf{X}_{\mathbf{i t}} \mathbf{\beta}+\text { Consol }_{\mathbf{i t}} \gamma\right)}}, \alpha, \boldsymbol{\beta}$ and $\gamma$ are the vectors of the parameters to be estimated and $\Phi(\cdot)$ is the logistic function. These parameters are estimated using maximum likelihood and the variance of the estimated coefficients can be expressed as

$$
\operatorname{Var}(\hat{\vartheta})=\left(\mathbf{Z}^{\prime} \mathbf{V Z}\right)^{-1}
$$

where $\boldsymbol{V}$ is a diagonal matrix, with diagonal entries equal to $\Phi(\cdot) \cdot[1-\Phi(\cdot)]$. 
In the case of rare events such as financial reforms $\Phi(\cdot)$ will be generally small. However, as pointed out by King and Zeng (1999a, 1999b, 2001), the estimates of $\Phi(\cdot)$ and $\Phi(\cdot) \cdot[1-\Phi(\cdot)]$ among observations for which rare events are observed (in our case, for which FinRef $=1$ ) will be typically larger than those among observations for which rare events are not observed (i.e. for which FinRef $=0$ ). Consequently, their contribution to the variance will be smaller rendering that additional 'rare' events will be more informative than additional 'frequent' events. Therefore, we follow King and Zeng (1999a, 1999b, 2001) and correct for the small sample and rare events bias, and estimate a rare events logit model where the sampling design is random or conditional on $\mathrm{Z}_{\mathrm{it} .}{ }^{4}$

\section{Data}

We use a panel dataset consisting of OECD countries. The limited time span of financial reforms and the few number of fiscal consolidation episodes reduce the number of countries in the estimation to at most 17 over the period 1980-2005.

\subsection{Financial reforms}

To identify financial reforms, we use the aggregate reform index from Abiad et al. (2008). These authors combine seven dimensions of financial liberalization to construct a single country-specific liberalization index that ranges between 0 and 21 , where higher scores denote a higher degree of financial liberalization.

To track policy changes affecting specific areas of the financial sector, we also consider the following indices: a) banking sector liberalization index; b) domestic finance liberalization index; and c) capital account liberalization index. The first two are computed as the sum of a variety of dimensions of liberalization as provided Abiad et al. (2008), ${ }^{5}$ along which a country is given a score on a graded scale, with zero corresponding to the case of full repression and three to the case of full liberalization. Finally, the capital account liberalization index from Abiad et al. (2008) is used to track reforms aimed at promoting international capital flows. More specifically, it measures the ease of financial credits and personal capital transactions restrictions which are often imposed to give control over the flow of credit within the economy, as well as greater control over the exchange rate, to the government. It is also coded from zero (in the case of full repression) to three (for full liberalization).

\footnotetext{
${ }^{4}$ We use the software package 'relogit' provided by Tomz et al. (1999).

${ }^{5}$ These are: banking supervision and regulation, credit controls, direct credit and reserve requirements, entry barriers, interest rate controls and banking privatization.
} 
From a methodological point of view and in order to consistently estimate model (1), we assume that the dependent variable, FinRef, takes the value of one if the year-on-year change in the aggregate reform index is greater or equal to one, and zero otherwise. Thereby, this indicates that, regardless the degree of liberalization attained, a reform process has been undertaken during the year. Analogously, while assessing the likelihood of reforms in a specific financial dimension, FinRef takes the value of one if the year-on-year change of subindex a), b) or c) (discussed above) is greater or equal to one, and zero otherwise.

\subsection{Fiscal Consolidations}

Fiscal consolidation episodes are assessed by a narrative approach pioneered by the work of Romer and Romer (2010). Rather than looking at fiscal outcomes, Devries et al. (2011) identify policy actions that aim at reducing the public deficit by examining accounts and records of what countries were intending to do at the time of the official IMF and OECD publications. Consequently, by tracking the decisions of policymakers, this approach eliminates the endogeneity of the response of fiscal policy to economic developments. For each of the 17 OECD countries included in their analysis, the authors widely document the characteristics of all the fiscal consolidation plans implemented by the national governments over the period 1978-2009.

Based on Devries' et al. (2011) dataset, we construct a variety of dummy variables to account for the duration of the fiscal consolidation episodes (i.e., the number of consecutive years of consolidation) and their typology (i.e., spending vs. tax-driven austerity plans). More specifically, we consider the following dummy variables:

- Consolidation period, which takes the value of one during fiscal consolidation episodes, and zero otherwise;

- Spending-driven consolidation, which takes the value of one when fiscal consolidation programs mainly consist of spending-cuts, and zero otherwise; and

- Tax-driven consolidation, which takes the value of one when consolidation plans mainly consist of tax-hikes, and zero otherwise.

We also control for the size effects of fiscal consolidation by considering the following variables:

- Consolidation size, which measures the total size of the fiscal consolidation program (as percentage of GDP); 
- Spending cuts, which measures the amount of spending cuts (as percentage of GDP) as defined in the fiscal consolidation program; and

- Taxes hikes, which measures the amount of tax increases (as percentage of GDP) as defined in the fiscal consolidation program.

\subsection{Additional Control Variables}

We augment the model specification by including a set of economic variables which, according to the empirical literature presented in section 2, are expected to significantly impact on the probability of implementation of financial reforms. In particular, we consider the following variables provided by the World Bank's World Development Indicators (WDI):

- the interest rate spread;

- the inflation rate;

- the merchandise trade as percentage of GDP; and

- the real effective exchange rate.

In addition, we construct the dummy variable contraction, which takes the value of one if the annual growth rate of the real GDP is negative, and zero otherwise. Data on GDP are retrieved from the WDI database.

\section{Empirical Results}

We start by investigating whether (and to which extent) the characteristics of fiscal consolidation (i.e. duration, composition and size) impact on the likelihood of financial reforms, while accounting for the effects of other relevant economic variables.

The results are summarized in Table 1. Looking at the columns 1-3, it seems that the occurrence of consolidation events does not promote the implementation of new reforms per se. Nevertheless, when we control for their size (columns 4-6), we find that larger consolidation packages, especially those related to spending cuts, increase the likelihood of a financial reform taking place. From a policy making perspective, this means that an episode of fiscal consolidation is not enough to generate a financial reform; instead, it must be of substantial size to signal enough credibility to the consolidation and to show that the authorities are committed to restoring a sound fiscal stance for a financial reform to take place. On the other hand, tax hikes do not seem to boost financial reforms.

We also uncover an important role for some economic factors, particularly inflation and the degree of trade openness. On one hand, the likelihood of a financial reform increases 
with higher price levels. This means that the erosion that inflation causes in the real value of financial assets tends to hasten the necessary reforms. On the other hand, the degree of trade openness exerts a negative and significant effect on the likelihood of financial reforms. Thus, higher openness appears to act as an automatic stabiliser, as it reduces the need of any reformdriven change in domestic demand. Additionally, we observe that during economic contractions, when interest rate spread rises and there is a real appreciation of the exchange rate, the likelihood of financial reforms increases, despite the fact that this effect is not statistically relevant in many cases. Nevertheless, these results seem to indicate that worst economic conditions tend to boost reforms (as in Drazen and Grilli (1993)).

\section{[Insert Table 1 here]}

Our first set of empirical results is based on an aggregate financial reform index and does not corroborate the existence of a significant role for fiscal consolidation programs in the implementation of financial reforms. However, financial innovation tends to germinate in times of crisis and, by improving future growth prospects, financial sector reforms may help mobilizing household's savings and improving the efficiency of capital allocation (Ranciere et al., 2006). Thus, we move on into a disaggregation of the general index by its subcomponents.

Looking more closely at the banking sector, domestic finance and capital account indices yield the results displayed in Tables 2, 3 and 4, respectively. Table 2 provides empirical evidence about the impact of fiscal consolidations on banking reforms. In this case, when a fiscal consolidation is implemented the likelihood of this kind of reforms does increase. In particular, consolidations that are driven by revenue or tax-related changes (Column 3) are prone at raising the probability of banking sector reforms. Moreover, the size of fiscal consolidation programs matters and helps promoting the implementation of banking sector reforms (Column 4). However, the size of spending cuts seems to matter more than those of tax hikes. This may be explained by a policy shift towards a more efficient, progressive and less distortionary tax system. Fiscal consolidations usually imply increasing tax rates or broadening the tax base by fighting evasion. Additionally, structural reforms contribute to reduce the deadweight-loss of the tax system for the economy with the elimination of rents and inefficiencies. 
As in the case of Table 1, banking sector reforms are also speeded up when both the interest rate spread and inflation rate increase, and when the degree of trade openness decreases. . Once again, worst economic conditions boost these reforms. ${ }^{6}$

\section{[Insert Table 2 here]}

Concerning domestic finance reforms (see Table 3), the results confirm the important role that fiscal consolidations have on this type of reforms. In particular, the size of consolidation packages largely explains the likelihood of domestic finance reforms: the higher the frequency of consolidation plans (column 1), the larger their size (column 4) and, notably, the bigger the spending-cuts (column 5) is, the higher the probability of implementing domestic finance reforms will be.

Additionally, some economic factors such as the interest rate spread, the inflation rate and the degree of trade openness help explaining the likelihood of domestic finance reforms: while an increase in interest rate spreads and inflation rate strongly boosts domestic finance reforms, countries that are more open to international trade are less likely to implement this type of reforms.

\section{[Insert Table 3 here]}

With regard to capital account reforms, our empirical findings suggest that fiscal consolidation episodes do not play any significant role (Table 4). That said, we still confirm the importance of economic factors such as the inflation rate and the real effective exchange rate, that is, an increase in the inflation rate raises the likelihood of capital account reforms, while an appreciation of the real effective exchange rate leads to a decrease in that same likelihood, which indicates, once again, that when things get tougher, reforms are hastened.

\section{[Insert Table 4 here]}

\footnotetext{
${ }^{6}$ Note that Contraction and real effective exchange rate also have positive coefficients, suggesting the same conclusion. However, their coefficients estimates are not statistically significant at usual levels.
} 


\section{Robustness checks}

As a robustness check, we estimate the same set of specifications using traditional probit and logit models. The results are presented in Tables 5-8. Columns 1-6 report the results from the probit estimations, while columns 7-12 provide the evidence for the logit regressions.

In general, there are no qualitatively major changes in the results and conclusions: (i) fiscal consolidations increase the likelihood of banking and domestic finance reforms, with tax-driven reforms being also important for banking reforms; (ii) the size of consolidation packages matter significantly for all types of financial reforms (except for capital account reforms), in particular, those that more heavily rely on spending cuts; (iii) we also corroborate the importance attributed to some economic variables in the reforms analysed here. All in all, our conclusions are robust, independently of the econometric model used.

[Insert Table 5 here]

[Insert Table 6 here]

[Insert Table 7 here]

[Insert Table 8 here]

\section{Conclusion}

In this paper, we evaluate the effects of fiscal consolidation on the probability of the implementation of financial reforms. Relying on a rare events logit model as well as traditional probit and logit models and using annual data for a panel of 17 OECD countries over the period 1980-2005, we find that large spending-driven consolidation measures (in percentage of GDP) raise the likelihood of financial reforms. Moreover, domestic finance reforms are also more frequent when fiscal adjustments are put in place and banking sector reforms occur more often during periods of fiscal consolidation programs that are driven by tax hikes. These results can be explained by policy shifts towards a more efficient, progressive and less distortionary tax system in the context of fiscal consolidation programs. Additionally, banking crises may lead to a collapse of the economy and a sharp decrease in government revenue. This, in turn, may require large packages to rescue financial institutions in trouble and to restore the health of the financial system, which severely deteriorates the 
stance of public finances (Reinhart and Rogoff, 2009, 2011a, 2011b) and forces governments to design and launch fiscal consolidation strategies. Under such circumstances, fiscal adjustments can pave the way for important reforms of the banking sector. Our empirical evidence corroborates such this line of argumentation.

Controlling for a set of macroeconomic variables, the empirical findings also suggest that (i) the higher inflation, (ii) the lower degree of trade openness, (iii) the weaker the financial conditions, and (iii) the less competitive the economy is, the higher the probability of financial reforms. Therefore, by reducing the need of structural reforms, the degree of trade openness acts as an automatic stabiliser. By contrast, when interest rate spreads increase, financial reforms are more likely to occur. Similarly, inflationary periods seem to create incentives for the implementation of financial reforms. Finally, fluctuations in the real effective exchange rate promote capital account reforms.

Since the beginning of the Great Recession, many countries began enacting several structural reforms, often in tandem with the application of fiscal consolidation programs. On the one hand, while the latter is necessary to restore fiscal sustainability, regain external credibility and lower sovereign risk premium and the former is needed to reduce complexity, increase transparency, enhance accountability mechanisms and the overall resilience of, for instance, the financial sector to shocks, time may be too short for the benefits of such efforts to materialize and to be recap by present generations. Moreover, the risk of both adjustment and reform fatigue (resulting from the absence of intergenerational wealth transfer considerations and agents' short-sightedness) can fuel social dissatisfaction, lead to political instability and undermine the progress achieved to date. Hence, while ultimately contributing to boost potential output in the future, policy makers should carefully select an appropriately balanced menu of consolidation measures and structural reforms worth undertaking with intergenerational concerns in mind, so that the burden does not, unnecessarily and unfairly, fall too much on the current generation.

On the other hand, as progress is made on the financial reform front, governments' credibility expands and markets come to understand the positive implications for fiscal sustainability (e.g. avoidance of bank capitalization public programs), risk premium may decline faster. This can lead to larger and possibly bigger improvements in real economic activity. In addition, if financial reforms are implemented at a reasonable pace such that households and firms can be quickly convinced that there will be no unwinding of such reforms in the future, then the benefits of those reforms will materialize much sooner with positive spillovers affecting different components of aggregate demand. 


\section{References}

Abiad, A., and A. Mody, 2005. Financial reform: What shakes it? What shapes it? American Economic Review, 95(1), 66-88.

Adam, C.S., Bevan, D.L., Gupta, S., and S. Radelet, 2003. Staying the course: Maintaining fiscal control in developing countries. Brookings Trade Forum, Brookings Institution Press: Washington, D.C., 167-227.

Agnello, L., Castro, V., and R. M. Sousa, 2013a. What determines the duration of a fiscal consolidation program? Journal of International Money and Finance, 37, 113-134.

Agnello, L., Castro, V., and R. M. Sousa, 2013b. Is fiscal fatigue a threat to consolidation programmes? Environment \& Planning C: Government \& Policy, forthcoming.

Agnello, L., Castro, V., Jalles, J. T., and R. M. Sousa, 2014a. What determines the likelihood of structural reforms? Organization for Economic Co-Operation and Development, mimeo.

Agnello, L., Castro, V., Jalles, J. T., and R. M. Sousa, 2014b. Do debt crises boost financial reforms? Applied Economics Letters, forthcoming.

Agnello, L., Castro, V., Jalles, J.T., and R.M. Sousa, 2014c. Fiscal adjustments, labour market flexibility and unemployment. Economics Letters, 124(2), 231-235.

Agnello, L., Mallick, S.K., and R. M. Sousa, 2012. Financial reforms and income inequality. Economics Letters, 116(3), 583-587.

Anderson, D., Hunt B., and S. Snudden S., 2013. Fiscal consolidation in the euro area: How much can structural reforms ease the pain? International Monetary Fund, IMF Working Paper No. 211.

Annett, T., and X. Debrun, 2004. Implementing Lisbon: Incentives and constraints. Euro Area Policies: Selected issues. International Monetary Fund, IMF Staff Country Report, No. 235.

Baldacci, E., Clements, B., Gupta, S., and C. Mulas-Granados, 2004. Front-loaded or backloaded fiscal adjustments: What works in emerging market economies? International Monetary Fund, IMF Working Paper No. 157.

Bates, R., and A. Krueger, 1993. Generalizations arising from the country studies. In: Bates, R., and A. Krueger, (eds.). Political and economic interactions in economic policy reform: Evidence from eight countries. Oxford: Basil Blackwell.

Bean, C., 1998. The new UK monetary arrangements: A view from the literature. Economic Journal, 108(451), 1795-1809.

Bouthevillain, C., and G. Dufrénot, 2011. Are the effects of fiscal changes different in times of crisis and non crisis? The French case. Revue d'Économie Politique, 121(3), 371-407. 
Buti, M., 2006. Will the new Stability and Growth pact succeed? An economic and political perspective. European Commission, European Economy Economic Paper No. 241.

Buti, M., Roger, W., and A. Turrini, 2007. Is Lisbon far from Maastricht? Trade-offs and complementarities between fiscal discipline and structural reforms. CESifo Economic Studies, 55(1), 165-196.

Calmfors, L., 2001. Unemployment, labour market reform and monetary union. Journal of Labor Economics, 19, 265-289.

Deroose, S., and A. Turrini, 2005. The short-term budgetary impact of structural reforms. Evidence from a panel of EU countries. Centre for Economic Policy Research, CEPR Discussion Paper No. 5217.

Devries, P., Guajardo, J., Leigh, D., and A. Pescatori, 2011. A new action based dataset of fiscal consolidation. International Monetary Fund, IMF Working Paper No. 128.

Drazen, A., and V. Grilli, 1993. The benefit of crises for economic reforms. American Economic Review, 83(3), 598-607.

Duval, R., and J. Elmeskov, 2005. The effects of EMU on structural reforms in labour and product markets. Organization for Economic Co-Operation and Development, OECD Economics Department Working Paper No. 438.

European Commission, 2005. Public finances in EMU, European Economy, 3.

Gupta, S., Baldacci, E., Clements, B., and E. Tiongson, 2005. What sustains fiscal consolidations in emerging market countries? International Journal of Finance \& Economics, 10(4), 307-321.

Haggard, S., and R.R. Kaufman, 1992. The politics of economic adjustment: International constraints, distributive conflicts, and the State. Princeton: Princeton University Press.

IMF, 2004. Fostering structural reforms in industrial countries. World Economic Outlook: Advancing Structural Reforms. Washigton, DC, International Monetary Fund.

Jensen, J., and F. Wöhlbier, 2012. Improving tax governance in EU Member States: Criteria for successful policies. European Commission, European Economy Occasional Paper No. 114.

Johannesson Lindén, A., and C. Gayer, 2012. Possible reforms of real estate taxation: Criteria for successful policies. European Commission, European Economy Occasional Paper No. 119.

King, G., and Langche Zeng, 1999a. Logistic regression in rare events data. Harvard University, Department of Government, available from http://GKing.Harvard.Edu. 
King, G., and Langche Zeng, 1999b. Estimating absolute, relative, and attributable risks in case-control studies. Harvard University, Department of Government, available from http://GKing.Harvard.Edu.

King, G., and Langche Zeng, 2001. Explaining rare events in international relations. International Organization, 55(3), 693-715.

Nelson, J., 1990. Economic crisis and policy choice: The politics of adjustment in the Third World. Princeton: Princeton University Press.

Padoan, P.C., Sila, U., and P. van den Noord, 2012. Avoiding debt traps: Fiscal consolidation, financial backstops and structural reforms. OECD Journal: Economic Studies, 2012(1), 151-177.

Padoan, P.C., Sila, U., and P. van den Noord, 2013. The Euro's future begins now: Escaping debt traps and moving towards sustainable growth. VoxEU.org, 5 May.

Ranciere, R., Tornell, A., and F. Westermann, 2006. Decomposing the effects of financial liberalization: Crises vs. growth. Journal of Banking and Finance, 30, 3331-3348.

Reinhart, C. M., and K.S. Rogoff, 2009. This time is different: A panoramic view of eight centuries of financial crises. Princeton University Press.

Reinhart, C. M., and K.S. Rogoff, 2011a. From financial crash to debt crises. American Economic Review, 101(5), 1676-1706.

Reinhart, C. M., and K.S. Rogoff, 2011b. The forgotten history of domestic debt. The Economic Journal, 121(552), 319-350.

Rodrik, D., 1996. Understanding economic policy reform. Journal of Economic Literature, 34(1), 9-41.

Romer, D., and C. Romer, 2010. The macroeconomic effects of tax changes: Estimates based on a new measure of fiscal shocks. American Economic Review, 100(3), 763-801.

Teulings, C., 2012. Fiscal consolidation and reforms: Substitutes, not complements. VoxEU.org, 13 September.

Tomz, M., King, G., and L. Zeng, 1999. RELOGIT: Rare Events Logistic Regression, Version 1.1 Cambridge, MA: Harvard University, October 1, http://gking.harvard.edu.

von Hagen, J., Hughes Hallett, A., and R. Strauch, 2002. Budgetary consolidation in Europe: Quality, economic conditions, and persistence. Journal of the Japanese and International Economics, 16, 512-535.

von Hagen, J., and R. Strauch, 2001. Fiscal consolidations: Quality, economic conditions, and success. Public Choice, 109, 327-346. 


\section{List of Tables}

Table 1: Financial reforms and fiscal consolidation - rare events logistic regression.

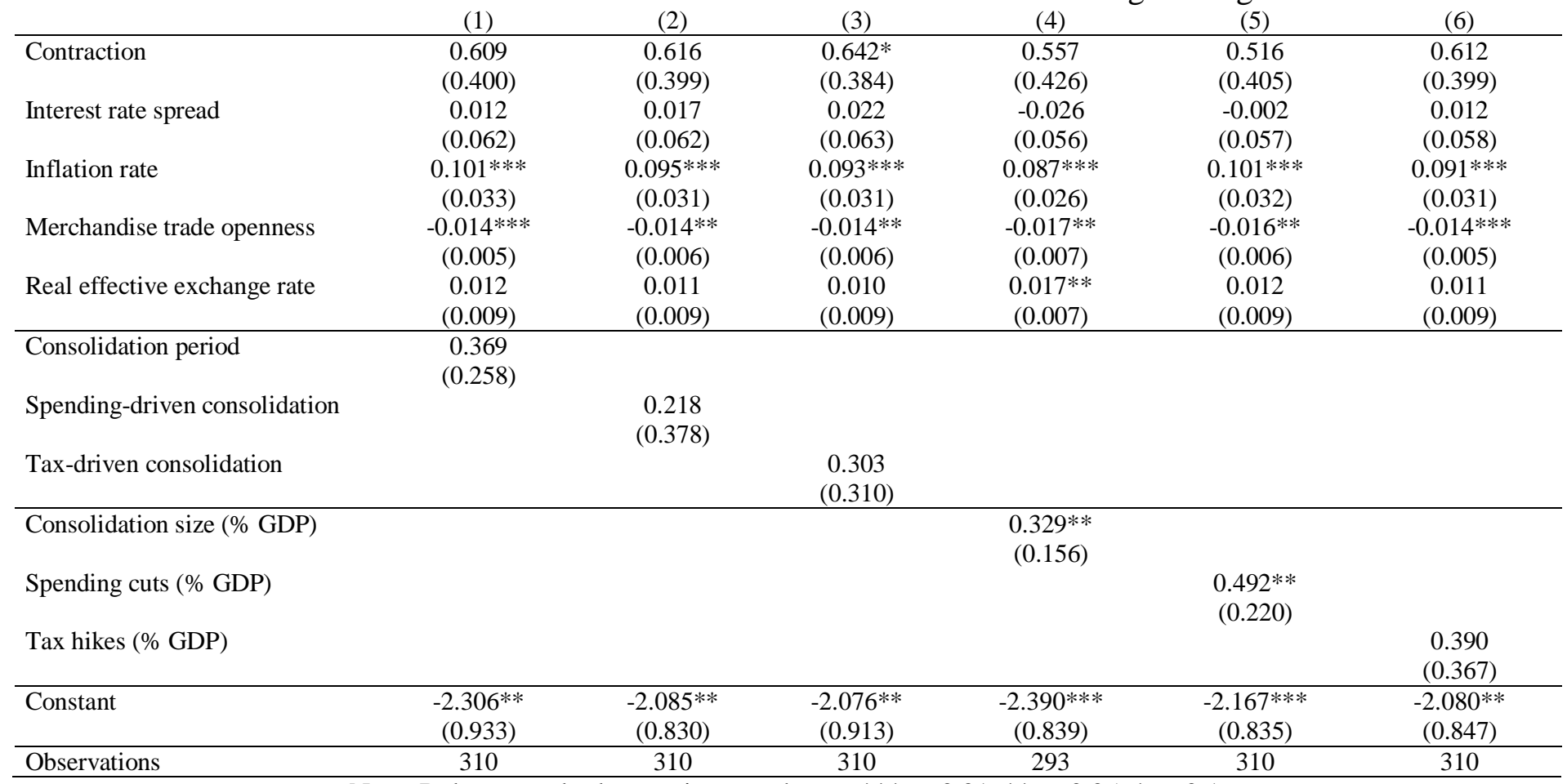

Note: Robust standard errors in parentheses. $* * * \mathrm{p}<0.01, * * \mathrm{p}<0.05, * \mathrm{p}<0.1$. 
Table 2: Banking sector reforms and fiscal consolidation - rare events logistic regression.

\begin{tabular}{|c|c|c|c|c|c|c|}
\hline & $(1)$ & $(2)$ & (3) & (4) & $(5)$ & $(6)$ \\
\hline \multirow[t]{2}{*}{ Contraction } & 0.383 & 0.405 & 0.442 & 0.357 & 0.319 & 0.398 \\
\hline & $(0.459)$ & $(0.454)$ & $(0.435)$ & $(0.491)$ & $(0.472)$ & $(0.447)$ \\
\hline \multirow[t]{2}{*}{ Interest rate spread } & $0.105^{*}$ & $0.113 * *$ & $0.119 * *$ & $0.090^{*}$ & $0.101 * *$ & $0.108 * *$ \\
\hline & $(0.054)$ & $(0.050)$ & $(0.052)$ & $(0.050)$ & $(0.049)$ & $(0.048)$ \\
\hline \multirow[t]{2}{*}{ Inflation rate } & $0.078 * * *$ & $0.069 * * *$ & $0.066 * * *$ & $0.065 * * *$ & $0.071 * * *$ & $0.063 * * *$ \\
\hline & $(0.028)$ & $(0.026)$ & $(0.022)$ & $(0.023)$ & $(0.025)$ & $(0.022)$ \\
\hline \multirow[t]{2}{*}{ Merchandise trade openness } & $-0.014 * *$ & $-0.014 * *$ & $-0.013^{* *}$ & $-0.015^{* *}$ & $-0.015^{* *}$ & $-0.014 * *$ \\
\hline & $(0.006)$ & $(0.006)$ & $(0.006)$ & $(0.007)$ & $(0.007)$ & $(0.006)$ \\
\hline \multirow{2}{*}{ Real effective exchange rate } & 0.002 & 0.000 & 0.000 & 0.004 & 0.001 & 0.000 \\
\hline & $(0.007)$ & $(0.006)$ & $(0.006)$ & $(0.005)$ & $(0.006)$ & $(0.006)$ \\
\hline Consolidation period & $\begin{array}{l}0.591^{*} \\
(0.316)\end{array}$ & & & & & \\
\hline Spending-driven consolidation & & $\begin{array}{c}0.289 \\
(0.417)\end{array}$ & & & & \\
\hline Tax-driven consolidation & & & $\begin{array}{c}0.591 * * \\
(0.280)\end{array}$ & & & \\
\hline Consolidation size (\% GDP) & & & & $\begin{array}{l}0.304^{*} \\
(0.170)\end{array}$ & & \\
\hline Spending cuts ( $\%$ GDP) & & & & & $\begin{array}{l}0.410 * \\
(0.243)\end{array}$ & \\
\hline Tax hikes (\% GDP) & & & & & & $\begin{array}{c}0.440 \\
(0.327)\end{array}$ \\
\hline Constant & $\begin{array}{c}1.978^{* *} \\
(0.781)\end{array}$ & $\begin{array}{c}-1.574^{* *} \\
(0.680)\end{array}$ & $\begin{array}{c}-1.639^{* *} \\
(0.711)\end{array}$ & $\begin{array}{c}-1.837 * * * \\
(0.645)\end{array}$ & $\begin{array}{c}-1.597 * * \\
(0.672)\end{array}$ & $\begin{array}{c}-1.555^{* *} \\
(0.669)\end{array}$ \\
\hline Observations & 310 & 310 & 310 & 293 & 310 & 310 \\
\hline
\end{tabular}

Note: Robust standard errors in parentheses. ${ }^{* * *} \mathrm{p}<0.01, * * \mathrm{p}<0.05, * \mathrm{p}<0.1$.


Table 3: Domestic finance reforms and fiscal consolidation - rare events logistic regression.

\begin{tabular}{|c|c|c|c|c|c|c|}
\hline & $(1)$ & (2) & (3) & (4) & $(5)$ & $(6)$ \\
\hline \multirow[t]{2}{*}{ Contraction } & 0.294 & 0.301 & 0.341 & 0.229 & 0.189 & 0.302 \\
\hline & $(0.469)$ & $(0.466)$ & $(0.462)$ & $(0.485)$ & $(0.466)$ & $(0.469)$ \\
\hline \multirow[t]{2}{*}{ Interest rate spread } & $0.091^{*}$ & $0.096^{*}$ & $0.104 * *$ & 0.063 & 0.079 & $0.093 *$ \\
\hline & $(0.052)$ & $(0.051)$ & $(0.049)$ & $(0.050)$ & $(0.049)$ & $(0.048)$ \\
\hline \multirow[t]{2}{*}{ Inflation rate } & $0.086^{* * *}$ & $0.080 * * *$ & $0.075 * * *$ & $0.074 * * *$ & $0.084 * * *$ & $0.073 * * *$ \\
\hline & $(0.026)$ & $(0.025)$ & $(0.023)$ & $(0.021)$ & $(0.024)$ & $(0.023)$ \\
\hline \multirow[t]{2}{*}{ Merchandise trade openness } & $-0.015 * * *$ & $-0.015 * * *$ & $-0.014 * * *$ & $-0.017 * * *$ & $-0.016^{* * * *}$ & $-0.014 * * *$ \\
\hline & $(0.005)$ & $(0.005)$ & $(0.005)$ & $(0.006)$ & $(0.006)$ & $(0.005)$ \\
\hline \multirow{2}{*}{ Real effective exchange rate } & 0.004 & 0.002 & 0.001 & 0.007 & 0.003 & 0.002 \\
\hline & $(0.009)$ & $(0.008)$ & $(0.008)$ & $(0.007)$ & $(0.008)$ & $(0.008)$ \\
\hline Consolidation period & $\begin{array}{c}0.516^{* * *} \\
(0.238)\end{array}$ & & & & & \\
\hline Spending-driven consolidation & & $\begin{array}{c}0.360 \\
(0.347)\end{array}$ & & & & \\
\hline Tax-driven consolidation & & & $\begin{array}{c}0.365 \\
(0.310)\end{array}$ & & & \\
\hline Consolidation size (\% GDP) & & & & $\begin{array}{c}0.380 * * * \\
(0.123)\end{array}$ & & \\
\hline Spending cuts (\% GDP) & & & & & $\begin{array}{c}0.548 * * * \\
(0.197)\end{array}$ & \\
\hline Tax hikes (\% GDP) & & & & & & $\begin{array}{c}0.458 \\
(0.311) \\
\end{array}$ \\
\hline Constant & $\begin{array}{l}-1.815^{*} \\
(0.926)\end{array}$ & $\begin{array}{l}-1.537 * \\
(0.808)\end{array}$ & $\begin{array}{l}-1.465^{*} \\
(0.844)\end{array}$ & $\begin{array}{c}-1.772 * * \\
(0.772)\end{array}$ & $\begin{array}{c}-1.557 * * \\
(0.782)\end{array}$ & $\begin{array}{l}-1.471^{*} \\
(0.777)\end{array}$ \\
\hline Observations & 310 & 310 & 310 & 293 & 310 & 310 \\
\hline
\end{tabular}

Note: Robust standard errors in parentheses. $* * * \mathrm{p}<0.01, * * \mathrm{p}<0.05, * \mathrm{p}<0.1$. 
Table 4: Capital account reforms and fiscal consolidation - rare events logistic regression.

\begin{tabular}{|c|c|c|c|c|c|c|}
\hline & (1) & $(2)$ & (3) & (4) & $(5)$ & (6) \\
\hline \multirow[t]{2}{*}{ Contraction } & 0.074 & 0.047 & -0.025 & -0.025 & 0.005 & -0.071 \\
\hline & $(0.705)$ & $(0.765)$ & $(0.724)$ & $(0.738)$ & $(0.775)$ & $(0.776)$ \\
\hline \multirow[t]{2}{*}{ Interest rate spread } & 0.010 & 0.009 & -0.008 & -0.040 & 0.001 & -0.010 \\
\hline & $(0.125)$ & $(0.131)$ & $(0.130)$ & $(0.133)$ & $(0.134)$ & $(0.137)$ \\
\hline \multirow[t]{2}{*}{ Inflation rate } & $0.141 * * *$ & $0.145^{* * *}$ & $0.158 * * *$ & $0.146 * * *$ & $0.156^{* * *}$ & $0.161 * * *$ \\
\hline & $(0.037)$ & $(0.041)$ & $(0.034)$ & $(0.034)$ & $(0.040)$ & $(0.037)$ \\
\hline \multirow[t]{2}{*}{ Merchandise trade openness } & -0.004 & -0.004 & -0.005 & -0.010 & -0.004 & -0.005 \\
\hline & $(0.011)$ & $(0.010)$ & $(0.010)$ & $(0.014)$ & $(0.010)$ & $(0.010)$ \\
\hline \multirow[t]{2}{*}{ Real effective exchange rate } & $0.038 * * *$ & $0.040 * * *$ & $0.043 * * *$ & $0.045 * * *$ & $0.043 * * *$ & $0.045^{* * *}$ \\
\hline & $(0.011)$ & $(0.012)$ & $(0.010)$ & $(0.012)$ & $(0.013)$ & $(0.012)$ \\
\hline Consolidation period & $\begin{array}{l}-0.913 \\
(0.698)\end{array}$ & & & & & \\
\hline Spending-driven consolidation & & $\begin{array}{c}-0.774 \\
(1.180)\end{array}$ & & & & \\
\hline Tax-driven consolidation & & & $\begin{array}{l}-0.184 \\
(0.986)\end{array}$ & & & \\
\hline Consolidation size (\% GDP) & & & & $\begin{array}{c}0.068 \\
(0.450)\end{array}$ & & \\
\hline Spending cuts (\% GDP) & & & & & $\begin{array}{l}-0.047 \\
(0.844)\end{array}$ & \\
\hline Tax hikes (\% GDP) & & & & & & $\begin{array}{c}0.412 \\
(0.499)\end{array}$ \\
\hline Constant & $\begin{array}{c}-6.906^{* * * *} \\
(1.403)\end{array}$ & $\begin{array}{c}-7.317 * * * \\
(1.536)\end{array}$ & $\begin{array}{c}-7.618^{* * * *} \\
(1.201)\end{array}$ & $\begin{array}{c}-7.423 * * * \\
(1.399)\end{array}$ & $\begin{array}{c}-7.708 * * * \\
(1.527)\end{array}$ & $\begin{array}{c}-7.963 * * * \\
(1.417)\end{array}$ \\
\hline Observations & 310 & 310 & 310 & 293 & 310 & 310 \\
\hline
\end{tabular}

Note: Robust standard errors in parentheses. ${ }^{* * *} \mathrm{p}<0.01, * * \mathrm{p}<0.05, * \mathrm{p}<0.1$. 
Table 5: Financial reforms and fiscal consolidation - probit and logit models.

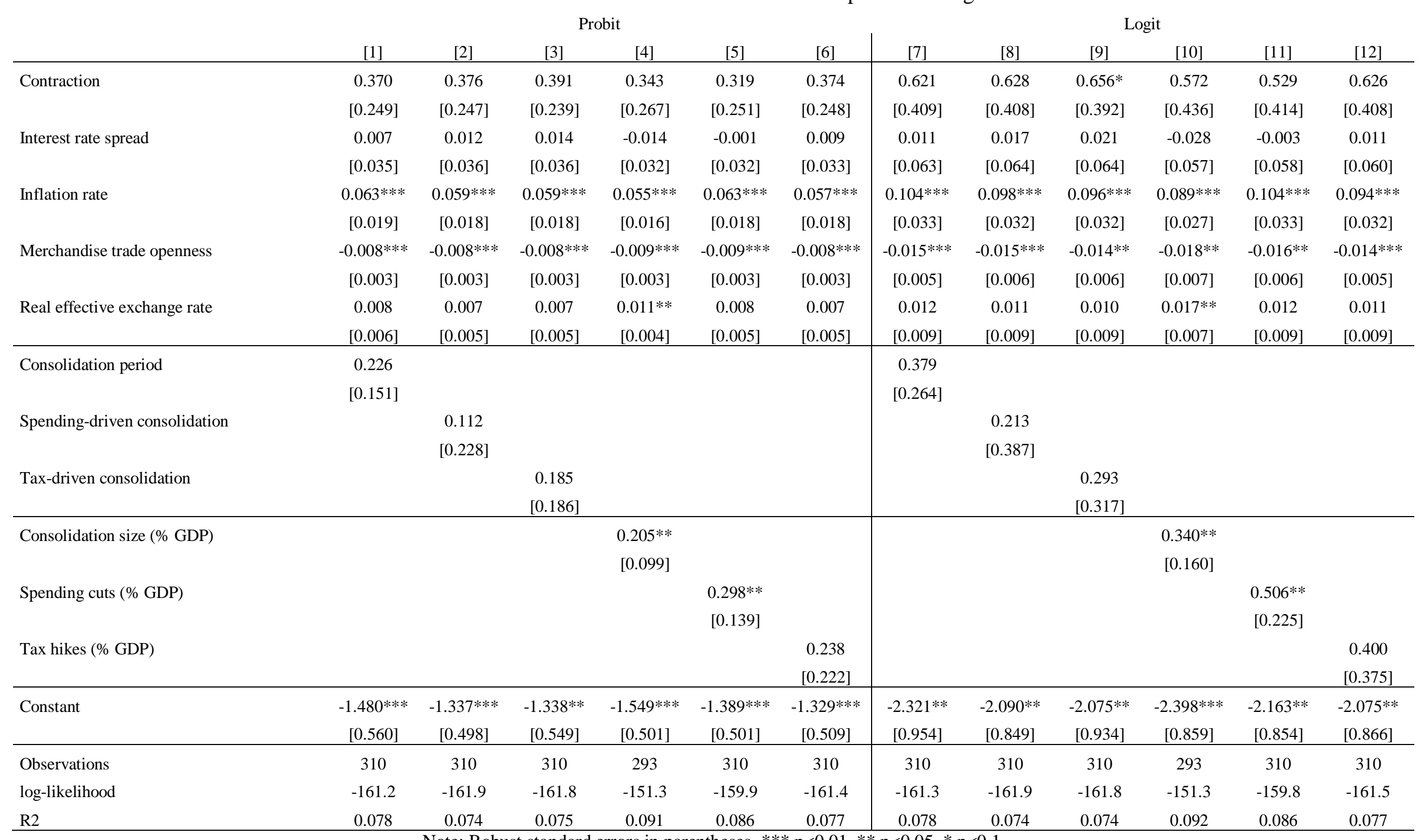


Table 6: Banking sector reforms and fiscal consolidation - probit and logit models.

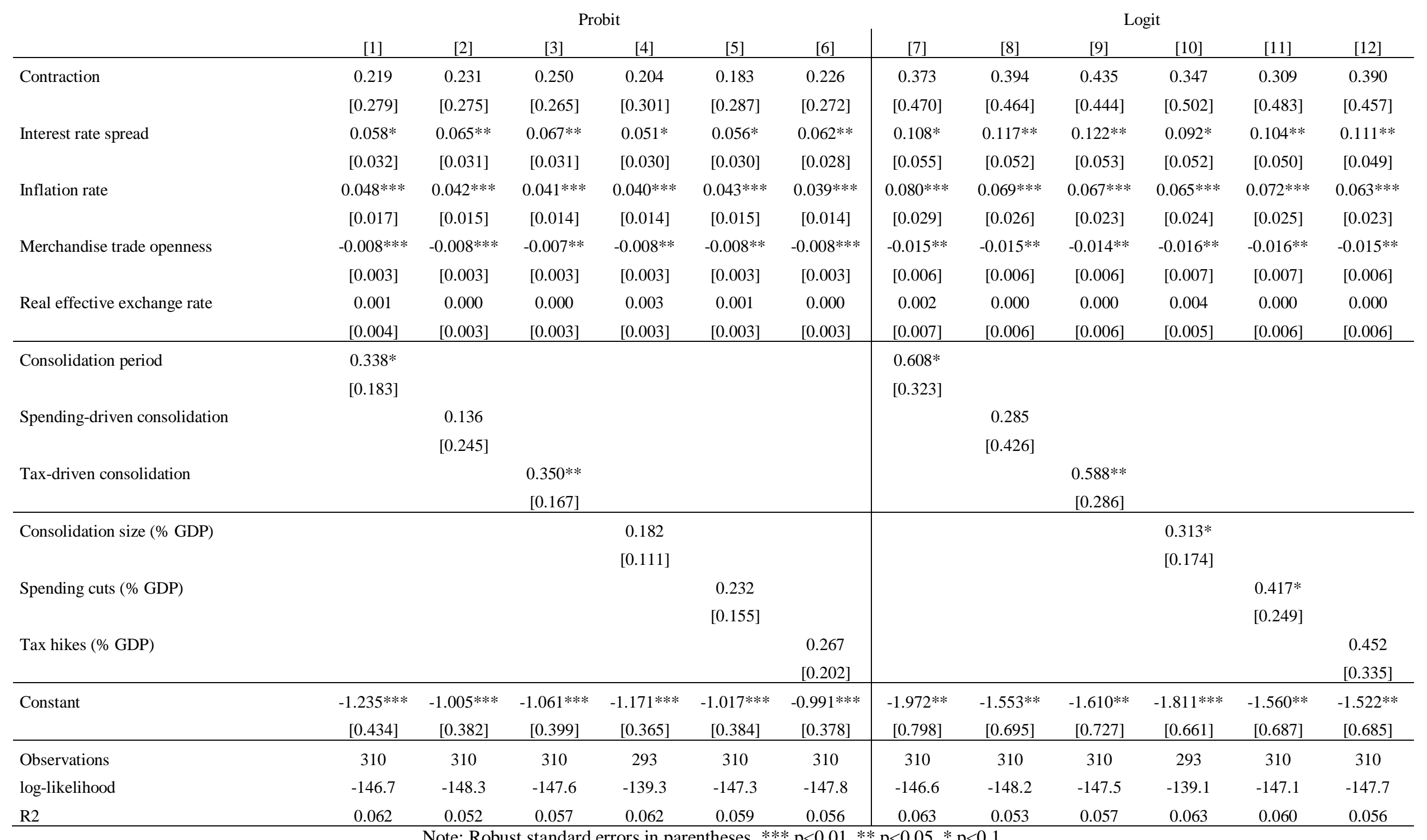


Table 7: Domestic finance reforms and fiscal consolidation- probit and logit models.

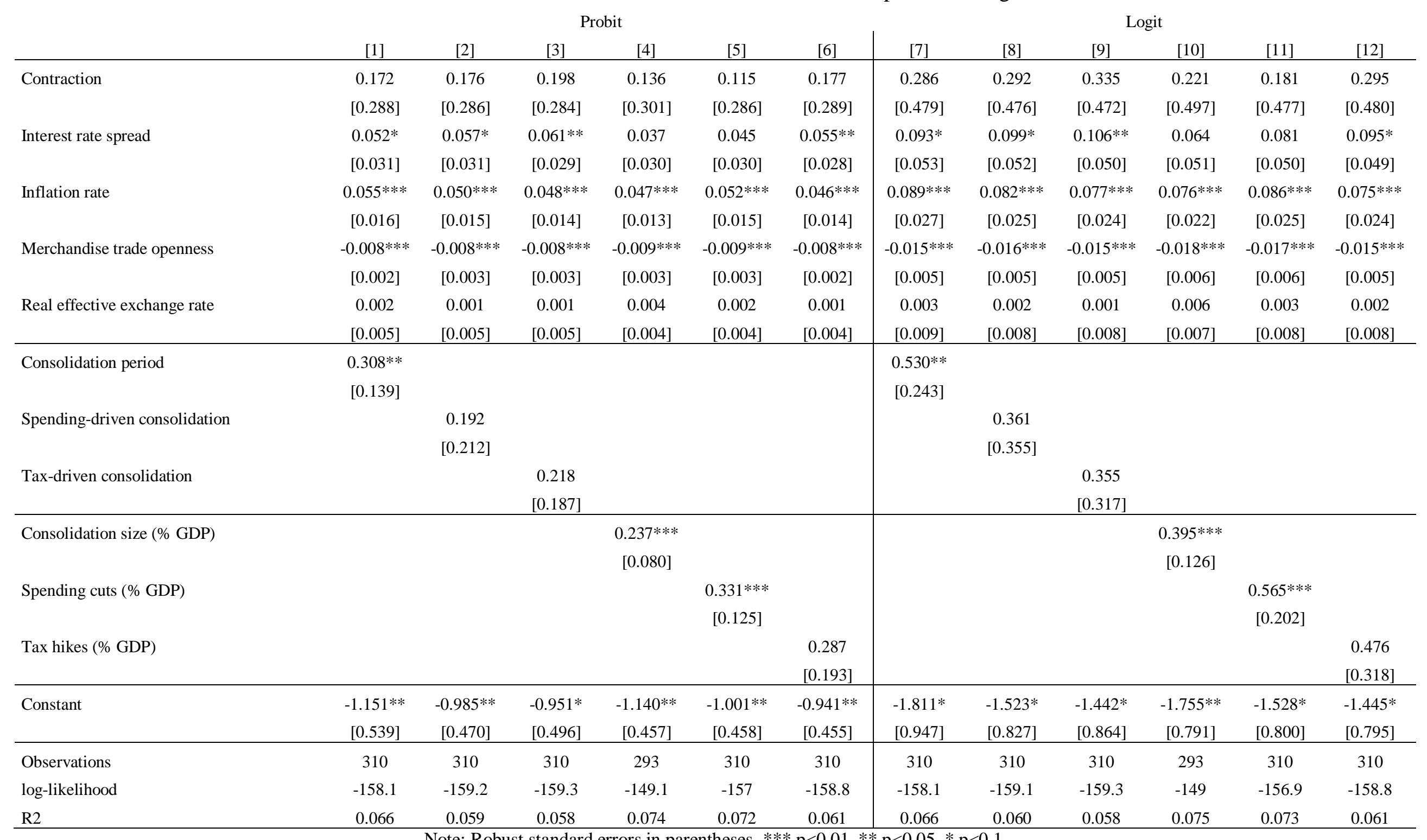


Table 8: Capital account reforms and fiscal consolidation - probit and logit models.

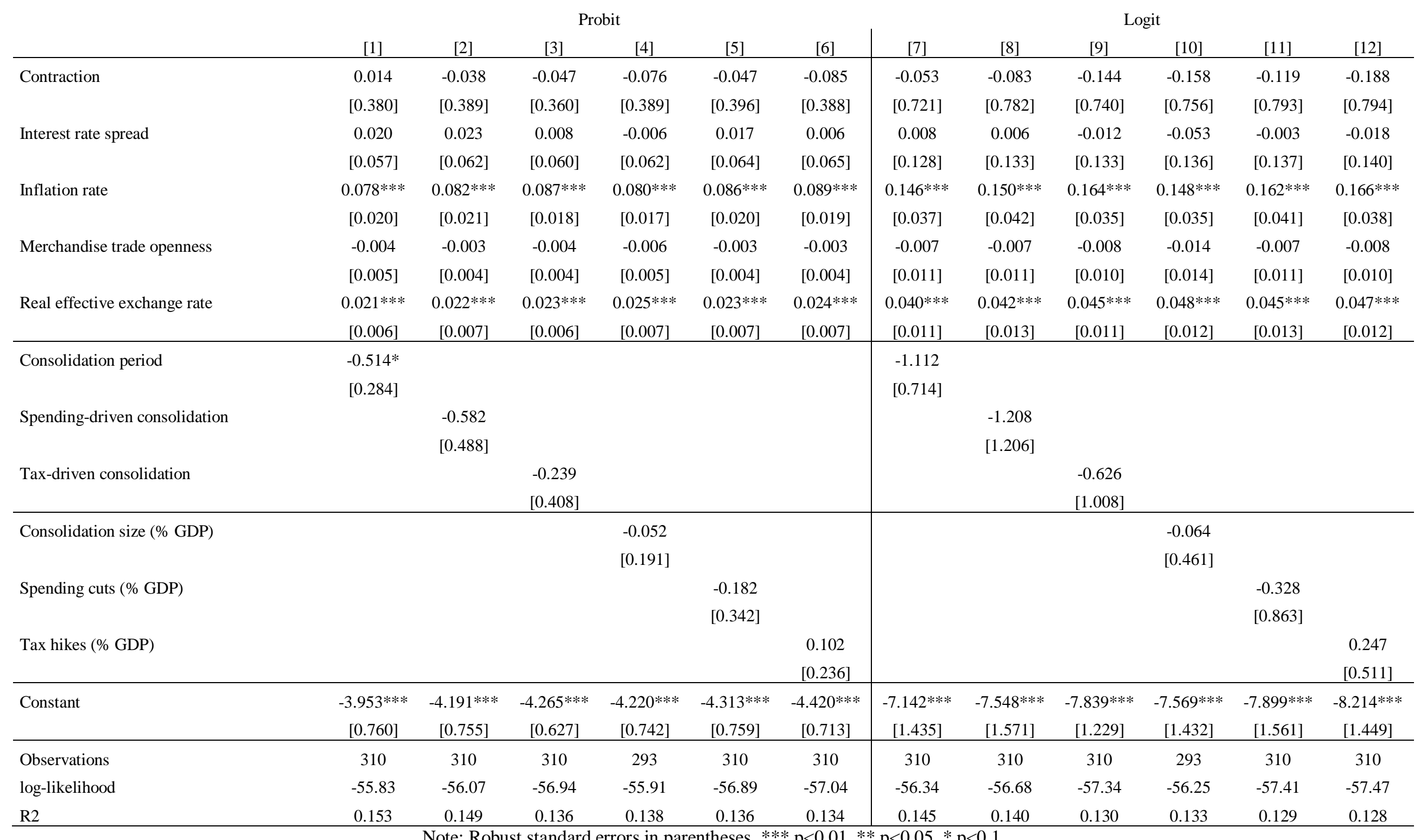

